\title{
Disruption of metal ion homeostasis in soils is associated with nitrogen deposition-induced species loss in an Inner Mongolia steppe
}

\author{
Q.-Y. Tian ${ }^{1, *}$, N.-N. Liu ${ }^{1,2, *}$, W.-M. Bai ${ }^{1}$, L.-H. Li ${ }^{1}$, and W.-H. Zhang ${ }^{1,3}$ \\ ${ }^{1}$ State Key Laboratory of Vegetation and Environmental Change, Institute of Botany, Chinese Academy of Sciences, \\ Beijing 100093, China \\ ${ }^{2}$ University of Chinese Academy of Sciences, Beijing 100049, China \\ ${ }^{3}$ Research Network of Global Change Biology, Beijing Institutes of Life Science, Chinese Academy of Sciences, \\ Beijing, China \\ *These authors contributed equally to this work.
}

Correspondence to: W.-H. Zhang (whzhang@ibcas.ac.cn)

Received: 28 November 2014 - Published in Biogeosciences Discuss.: 27 January 2015

Revised: 18 April 2015 - Accepted: 10 May 2015 - Published: 9 June 2015

\begin{abstract}
Enhanced deposition of atmospheric nitrogen (N) resulting from anthropogenic activities has negative impacts on plant diversity in ecosystems. Several mechanisms have been proposed to explain the species loss. Ion toxicity due to $\mathrm{N}$ deposition-induced soil acidification has been suggested to be responsible for species loss in acidic grasslands, while few studies have evaluated the role of soil-mediated homeostasis of ions in species loss under elevated $\mathrm{N}$ deposition in grasslands with neutral or alkaline soils. To determine whether soil-mediated processes are involved in changes in biodiversity induced by $\mathrm{N}$ deposition, the effects of 9-year $\mathrm{N}$ addition on soil properties, aboveground biomass (AGB) and species richness were investigated in an Inner Mongolia steppe. Low to moderate $\mathrm{N}$ addition rate $\left(2,4,8 \mathrm{~g} \mathrm{~N} \mathrm{~m}^{-2} \mathrm{yr}^{-1}\right)$ significantly enhanced AGB of graminoids, while high $\mathrm{N}$ addition rate ( $\geq 16 \mathrm{~g} \mathrm{~N} \mathrm{~m}^{-2} \mathrm{yr}^{-1}$ ) reduced AGB of forbs, leading to an overall increase in AGB of the community under low to moderate $\mathrm{N}$ addition rates. Forb richness was significantly reduced by $\mathrm{N}$ addition at rates greater than $8 \mathrm{~g} \mathrm{~N} \mathrm{~m}^{-2} \mathrm{yr}^{-1}$, while no effect of $\mathrm{N}$ addition on graminoid richness was observed, resulting in decline in total species richness. $\mathrm{N}$ addition reduced soil $\mathrm{pH}$, depleted base cations $\left(\mathrm{Ca}^{2+}, \mathrm{Mg}^{2+}\right.$ and $\mathrm{K}^{+}$) and mobilized $\mathrm{Mn}^{2+}, \mathrm{Fe}^{3+}, \mathrm{Cu}^{2+}$ and $\mathrm{Al}^{3+}$ ions in soils. Soil inorganic-N concentration was negatively correlated with forb richness and biomass, explaining $23.59 \%$ variation of forb biomass. The concentrations of base cations
\end{abstract}

$\left(\mathrm{Ca}^{2+}\right.$ and $\left.\mathrm{Mg}^{2+}\right)$ and metal ions $\left(\mathrm{Mn}^{2+}, \mathrm{Cu}^{2+}\right.$ and, $\left.\mathrm{Fe}^{3+}\right)$ showed positively and negatively linear correlation with forb richness, respectively. Changes in the metal ion concentrations accounted for $42.77 \%$ variation of forb richness, while reduction of base cations was not associated with the reduction in forb richness. These results reveal that patterns of plant biodiversity in the temperate steppe of Inner Mongolia are primarily driven by increases in metal ion availability, particularly enhanced release of soil $\mathrm{Mn}^{2+}$.

\section{Introduction}

Nitrogen $(\mathrm{N})$ is an essential nutrient for plant growth and development, and many terrestrial ecosystems are adapted to conditions of low $\mathrm{N}$ availability (Bobbink et al., 1998). Since the agricultural and industrial revolution, atmospheric deposition of biologically reactive $\mathrm{N}$ has increased drastically due to $\mathrm{N}$ fertilization and combustion of fossil fuels across the globe (Galloway et al., 2008; Canfield et al., 2010; Sutton and Bleeker, 2013), resulting in a large impact on community composition and function of ecosystems (De Schrijver et al., 2008; Cardinale et al., 2012; H. Yang et al., 2012). Elevated atmospheric $\mathrm{N}$ deposition generally has positive effects on productivity for the $\mathrm{N}$ limited ecosystems (Smith et al., 1999; Galloway et al., 2008), while it imposes a great threat to bio- 
diversity of the terrestrial ecosystems (Stevens et al., 2004; Clark and Tilman, 2008; Bobbink et al., 2010; Jiang et al., 2010; Kim et al., 2011). Both large-scale field survey and manipulated experiments to simulate $\mathrm{N}$ deposition have shown that $\mathrm{N}$ deposition has driven significant reductions in plant species richness in different grassland ecosystems (Stevens et al., 2004; Suding et al., 2005; Bai et al., 2010; Clark and Tilman, 2008, Dupre et al., 2010; Van Den Berg et al., 2011). Along with the time of $\mathrm{N}$ deposition or with the increase of $\mathrm{N}$ addition rate, the decline in species richness by $\mathrm{N}$ deposition consequently results in changes of community composition and reduction in ecosystem productivity (Isbell et al., 2013).

Several hypotheses have been proposed to explain the $\mathrm{N}$ deposition-induced species loss in grassland ecosystems, such as $\mathrm{NH}_{4}^{+}$toxicity to plants (van den Berg et al., 2005; Stevens et al., 2006; Zhang et al., 2014), soil acidification (van der Putten et al., 2013), mobilization of toxic metals in soils (Bowman et al., 2008; Horswill et al., 2008; Stevens et al., 2009; Chen et al., 2013) and changes in soil microbial activity and biodiversity (Dean et al., 2014). Competitive exclusion driven by enhanced resource uptake by dominant species and pre-emption of light or space has been widely invoked as a key mechanism for species loss under elevated $\mathrm{N}$ regimes (Clark and Tilman, 2008; Hautier et al., 2009; Suding et al., 2005; Borer et al., 2014). For instance, it has been suggested that chronic $\mathrm{N}$ deposition shifts grassland towards grass-dominated vegetation due to higher productivity of grasses at elevated $\mathrm{N}$ concentrations, which are thought to outcompete forbs and shrubs (Heil and Diemont, 1983; Bobbink et al., 1998; Stevens et al., 2006). However, $\mathrm{N}$ addition-induced reductions in plant biodiversity cannot simply be explained by competitive exclusion, because many species had already disappeared before grasses became dominant (Houdijk et al., 1993) and fertilization also reduces plant biodiversity of grassland even when light is not limiting (Dickson and Foster, 2011). Although extensive research has demonstrated that $\mathrm{N}$ deposition reduces biodiversity, the primary mechanism underlying the $\mathrm{N}$ depositioninduced changes in community composition remains largely unknown (Stevens et al., 2006; Phoenix et al., 2003; Bowman et al., 2008; Clark and Tilman, 2008; Hautier et al., 2009; Suding et al., 2005; Borer et al., 2014).

$\mathrm{N}$ deposition often concurs with soil acidification (Stevens et al., 2004; Bobblink et al., 2010; Fang et al., 2012; Horswill et al., 2008; Y. Yang et al., 2012). Soil acidification subsequently mobilizes some metal ions, thus rendering phytotoxicity to plants at high concentrations (Kochian, 1995; Marschner, 1995). For instance, release of toxic aluminum $\left(\mathrm{Al}^{3+}\right)$ ions due to soil acidification has been suggested to be a driving force for $\mathrm{N}$ deposition-induced species loss in grasslands (Carnol et al., 1997; Horswill et al., 2008; Chen et al., 2013). In addition to $\mathrm{Al}^{3+}$, homeostasis of other ions in soil is also closely determined by soil $\mathrm{pH}$, such that reduction in soil $\mathrm{pH}$ would enhance release of those metal ions of $\mathrm{Fe}^{3+}, \mathrm{Mn}^{2+}$ and $\mathrm{Cu}^{2+}$ (Marschner, 1995; Bowman et al.,
2008). The involvement of soil acidification-mediated processes in species loss under elevated $\mathrm{N}$ deposition has been extensively evaluated in acidic grasslands (Stevens et al., 2006; Bowman et al., 2008; Horswill et al., 2008). Whether this mechanism is also responsible for $\mathrm{N}$ deposition-induced changes in plant biodiversity in other types of grassland remains largely unknown. A major difference between acidic grasslands and temperate steppe used in the present study lies in their basic properties of soils, such as soil pH, ion contents and acid buffering systems. In acidic grasslands, soil $\mathrm{pH}$ is usually $<5.0$, and availabilities of metal ions, such as $\mathrm{Al}^{3+}$, $\mathrm{Fe}^{3+}, \mathrm{Mn}^{2+}$ are high compared to those in the alkaline soils, and acid buffering is mainly dependent on aluminium, leading to lower acid buffering capacity (Bowman et al., 2008). However, soils in neutral or alkaline grasslands have more base cations, higher acid buffering capacity and low availabilities of metal ions $\left(\mathrm{Al}^{3+}, \mathrm{Fe}^{3+}, \mathrm{Mn}^{2+}\right)$. In addition to the differences in soil traits, plants grown in acidic and alkaline grasslands may also have evolved adaptive strategies to their edaphic conditions. Plants in the alkaline temperate steppe would be exposed to high levels of metal concentrations due to $\mathrm{N}$ deposition-driven soil acidification, rendering them metal toxicity. Therefore, plants in the alkaline grasslands and acid grasslands may differ in their sensitivity to $\mathrm{N}$ deposition-induced changes in soil traits

Inner Mongolia grassland is an important part of widely distributed grasslands across the Eurasian Steppe with typical calcareous soil distinguished by high $\mathrm{pH}$ and buffering capacity due to abundant base cations (Chen et al., 2013). These differences in soil traits between the temperate steppes and acid grasslands may render the two types of grasslands differing in their sensitivity to $\mathrm{N}$ deposition. $\mathrm{N}$ deposition rate in China has increased dramatically in recent decades (Liu et al., 2013; Jia et al., 2014), thus imposing great threats to plant biodiversity in grassland ecosystems. Moreover, a significant soil acidification in grasslands across northern China over the past 2 decades has been reported (Y. Yang et al., 2012). In contrast to acidic grasslands, few studies have investigated the role of soil acidification-driven metal mobilization in species richness in calcareous and alkaline grasslands under conditions of elevated $\mathrm{N}$ deposition. To evaluate the role of soil-mediated chemical processes in $\mathrm{N}$ depositioninduced changes in species richness, the chronic effects of $\mathrm{N}$ addition, which simulates $\mathrm{N}$ deposition, on soil $\mathrm{pH}$, nutrient availability and species composition were investigated in a temperate steppe of Inner Mongolia.

\section{Materials and methods}

\subsection{Study site}

The field experiment was carried out in Duolun County $\left(116^{\circ} 17^{\prime} \mathrm{E}, 42^{\circ} 02^{\prime} \mathrm{N}\right)$, Inner Mongolia, China. The experiment site is located in a semi-arid temperate steppe with 
mean annual temperature of $2.1^{\circ} \mathrm{C}$. Mean annual precipitation is $382.2 \mathrm{~mm}$ with approximately $60-80 \%$ falling from May to August. Soil in the site is classified as chestnut type according to China's soil classification system (Hou, 1982) and Calcic-orthic Aridisol based on ISSS Working Group RB, 1998. The main characteristics of the soil include a chestnut color humus layer in topsoil, calccrust within $1 \mathrm{~m}$ on soil profile and soil $\mathrm{pH}$ between 7.0 and 9.0. Soil in the study is composed of $62.75 \pm 0.04 \%$ sand, $20.30 \pm 0.01 \%$ silt and $16.95 \pm 0.01 \%$ clay. Mean soil bulk density and soil $\mathrm{pH}$ is $1.31 \mathrm{~g} \mathrm{~cm}^{-3}$ and 6.84 , respectively. The net $\mathrm{N}$ mineralization rates in this area were -0.04 to $0.52 \mu \mathrm{g} \mathrm{N}^{-1} \mathrm{~g}^{-1}$ during the growing seasons (X. Zhang et al., 2012). The ambient total $\mathrm{N}$ deposition in this region was about $1.6 \mathrm{~g} \mathrm{~N} \mathrm{~m}^{-2} \mathrm{yr}^{-1}$ for the last 2 decades (Zhang et al., 2008). The community in this area is co-dominated by perennial forbs and graminoids, including Stipa krylovii, Artemisia frigida, Potentilla acaulis, Potentilla tanacetifolia, Dianthus chinensis, Heteropappus altaicus, Cleistogenes squarrosa, Allium bidentatum, Leymus chinensis, Carex korshinskyi, Melilotoides ruthenica, Agropyron cristatum, Potentilla bifurca, Allium tenuissimum, Poa pratensis and Koeleria cristata, in which the aboveground biomass (AGB) of forbs or grasses is about half of the total biomass. The detailed species characteristics of the vegetation were listed in Appendix Table A3.

\subsection{Experiment design}

The experiment site was fenced to exclude livestock grazing in July 2003. A total of 64 plots $(15 \mathrm{~m} \times 10 \mathrm{~m})$ were established and each of them was spaced by a $4 \mathrm{~m}$ width buffer strip. Eight levels of $\mathrm{N}$ addition (0, 1, 2, 4, 8, 16, 32, $\left.64 \mathrm{~g} \mathrm{~N} \mathrm{~m}^{-2}\right)$ were added as urea $(\mathrm{N}, 46 \%)$ with eight replicates by evenly spreading with hand in July every year since 2003. In our study, soil and plant samples were collected from 48 plots supplemented with six levels of $\mathrm{N}$ addition $\left(0,2,4,8,16,32 \mathrm{~g} \mathrm{~N} \mathrm{~m}^{-2}\right)$ in 2012.

\subsection{Determination of community biomass and composition, and soil sampling}

AGB of forbs and graminoids was separately determined at the peak biomass time in the middle of August in 2012 using a randomly selected quadrat $(1 \mathrm{~m} \times 1 \mathrm{~m})$ of each plot. The graminoids included S. krylovii, C. squarrosa, L. chinesis, A. cristatum, C. korshinskyi, $P$ pratensis, and $K$. cristata. The forbs included A. frigida, $P$. acaulis, $P$. tanacetifolia, D. chinensis, H. altaicus, A. bidentatum, M. ruthenica, P. bifurca and A. tenuissimum. AGB was harvested by clipping every quadrat completely above the soil surface, and both of living and dead parts were separated. Biomass was measured separately after samples were oven dried at $75^{\circ} \mathrm{C}$ for $48 \mathrm{~h}$.
Soil samples were collected from each quadrat. Topsoil samples $(0-10 \mathrm{~cm}$ below the litter layer) and subsoil samples $(20-30 \mathrm{~cm}$ deep) were taken randomly using a $10 \mathrm{~cm}$ diameter soil auger. Three-core soils were combined to one sample per quadrat. In this study, only soil samples from 0 to $10 \mathrm{~cm}$ layers were used. All soil samples were kept cool during transit and air dried in the laboratory. Soil samples were thoroughly mixed and sieved through a $2 \mathrm{~mm}$ mesh for laboratory analysis of soil $\mathrm{pH}$ and exchangeable ion concentrations.

\subsection{Measurements of soil $\mathrm{pH}$ and electrical conductivity}

For determination of soil $\mathrm{pH}, 6 \mathrm{~g}$ of air-dried soil was shaken with $15 \mathrm{~mL} \mathrm{CO}_{2}$-free deionized water for a minute, and equilibrated for an hour to determinate $\mathrm{pH}$ with a $\mathrm{pH}$ meter (HANNA, PH211, Italy). Water soluble salts in the soil solution are strong electrolytes to be electrical. The performance of electric conduction can be expressed as electrical conductivity (EC). The content of salts in the solution is positively correlated with EC, and EC can be determined by a conduct meter to represent the content of ions in soil. For determination of soil EC, $10 \mathrm{~g}$ of air-dried soil was shaken with $50 \mathrm{~mL} \mathrm{CO}_{2}$-free deionized water for three minutes, and filtered to get clear leachate for determination with the conduct meter (METTLER TOLEDO, FE30, Switzerland). EC was calculated with the following formula

$L=C \cdot f_{t} \cdot K$

where $L$ indicates electrical conductivity with $1: 5$ soil leachate at $25^{\circ} \mathrm{C}, \mathrm{C}$ indicates displayed electrical conductivity on the conduct meter, $f_{t}$ indicates correction coefficient of temperature and $K$ indicates electrode constant.

\subsection{Determination of available soil $P$ and inorganic- $\mathrm{N}$ concentrations}

Available $\mathrm{P}$ (Olsen-P) in soil was determined by extracting $10 \mathrm{~g}$ of air-dried soil with $50 \mathrm{~mL} 0.5 \mathrm{M} \mathrm{NaHCO}_{3}(\mathrm{pH} 8.5)$ for $30 \mathrm{~min}$ at $25^{\circ} \mathrm{C}$, and analyzed after filtering by molybdenum blue-ascorbic acid method (Olsen et al., 1954) with a UV-visible spectrophotometer (UV-2550, SHIMADZU Corporation, China).

Soil inorganic $\mathrm{N}\left(\mathrm{NH}_{4}^{+}-\mathrm{N}\right.$ and $\left.\mathrm{NO}_{3}^{-}-\mathrm{N}\right)$ using fresh soil was analyzed calorimetrically using a continuous-flow analyzer (Seal XY-2, Australia) after extraction of $2 \mathrm{M} \mathrm{KCl}$ at the ratio of $1: 5(w / v)$ (Mulvaney, 1996; Wendt, 1999).

\subsection{Determination of soil $\mathrm{Fe}^{3+}, \mathrm{Mn}^{2+}, \mathrm{Cu}^{2+}, \mathrm{Zn}^{2+}$ and $\mathrm{Al}^{3+}$}

The exchangeable $\mathrm{Mn}^{2+}, \mathrm{Fe}^{3+}, \mathrm{Cu}^{2+}, \mathrm{Zn}^{2+}$ in the soil were extracted with a extracting agent $(\mathrm{pH} 7.3)$ consisted of $5 \mathrm{mM}$ 
diethylenetriamine pentaacetic acid (DTPA), $10 \mathrm{mM} \mathrm{CaCl} 2$ and $0.1 \mathrm{M}$ triethanolamine (TEA) in $1: 2$ ratio $(w / v)$ for $2 \mathrm{~h}$ (Lindsay and Norvell, 1978). Exchangeable $\mathrm{Al}^{3+}$ in the soil was extracted by $0.1 \mathrm{M} \mathrm{BaCl}_{2}(\mathrm{pH} 5.3)$ at the ratio $1: 5(w / v)$ for $30 \mathrm{~min}$ (Bowman et al., 2008). After filtering, samples were stored frozen prior to analysis by ICP-OES (Thermo Electron Corporation, USA).

\subsection{Measurements of soil exchangeable $\mathrm{Ca}^{2+}, \mathrm{Mg}^{2+}$, $\mathbf{K}^{+}$}

Base cations $\left(\mathrm{Ca}^{2+}, \mathrm{Mg}^{2+}, \mathrm{K}^{+}\right)$in the soil were extracted by $1 \mathrm{M} \mathrm{NH}_{4} \mathrm{OAc}(\mathrm{pH} 7.0)$ at a $1: 10$ ratio $(w / v)$ for $30 \mathrm{~min}$. The extraction solution was filtered to determine the concentration of $\mathrm{Ca}^{2+}, \mathrm{Mg}^{2+}, \mathrm{K}^{+}$by ICP-OES.

\subsection{Statistical analysis}

One-way ANOVA (Duncan's test) was used to evaluate the difference in species richness, AGB, soil $\mathrm{pH}$ and soil EC among six levels of $\mathrm{N}$ addition. Linear regression was used to identify the significance of the correlation among soil exchangeable ions and $\mathrm{N}$ addition, soil $\mathrm{pH}$, species richness and AGB (SPSS 17.0). Principal component analysis (PCA) was used to extract the principal components of variables of the metal cations and to group them in terms of their high loading on principal axis (R. i386 3. 0. 3). A multiple regression model (GLM) was used to explore to what extent that species richness and AGB can be explained by ion changes in soils and which variables are responsible for $\mathrm{N}$ addition-induced changes in AGB and species richness (SPSS 17.0).

\section{Results}

\subsection{N addition enhanced aboveground biomass and reduced species richness}

At the community level, $\mathrm{N}$ addition at low rates stimulated plant growth and increased AGB of the steppe, and total AGB peaked $425.8 \mathrm{~g} \mathrm{~m}^{-2}$ at a $\mathrm{N}$ addition rate of $2 \mathrm{~g} \mathrm{~m}^{-2} \mathrm{yr}^{-1}$ $(P=0.007)$, and further increases in $\mathrm{N}$ addition rates led to a decline in AGB, such that values of AGB in plots added with $16(P=0.236)$ and $32 \mathrm{~g} \mathrm{~N} \mathrm{~m}^{-2} \mathrm{yr}^{-1}(P=0.695)$ were comparable to those in control plots (Fig. 1a). A similar pattern of $\mathrm{N}$ addition-induced increase in AGB of graminoids was found (Fig. 1c). $\mathrm{N}$ addition at low rates $\left(2-8 \mathrm{~g} \mathrm{~N} \mathrm{~m}^{-2} \mathrm{yr}^{-1}\right)$ had no effect on AGB of forbs, while it significantly reduced AGB of forbs at $16 \mathrm{~g} \mathrm{~N} \mathrm{~m}^{-2} \mathrm{yr}^{-1}(P=0.027$, Fig. 1c). Therefore, the increase in total AGB was driven entirely by the increase of graminoids biomass. In contrast to AGB, total species richness was significantly reduced at $\mathrm{N}$ addition rates of greater than $8 \mathrm{~g} \mathrm{~N} \mathrm{~m}^{-2} \mathrm{yr}^{-1}(P=0.025$, Fig. 1b). Moreover, graminoid richness was relatively insensitive to $\mathrm{N}$ addition, while a decline in forb richness was detected at $\mathrm{N}$ addition rate of $8 \mathrm{~g} \mathrm{~N} \mathrm{~m}^{-2} \mathrm{yr}^{-1}$, and the decline became stronger
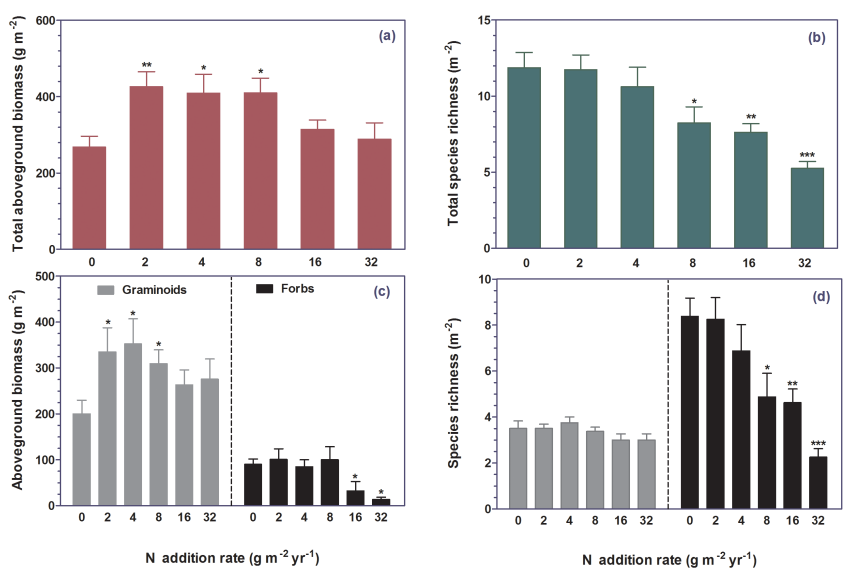

Figure 1. Effects of $\mathrm{N}$ addition on aboveground biomass (AGB) and species richness of vegetation. Total aboveground biomass (a), total species richness (b), graminoid and forb aboveground biomass (c) and species richness of graminoids and forbs (d) in plots with different rates of $\mathrm{N}$ addition. Number of species and AGB were determined in quadrats $(1 \mathrm{~m} \times 1 \mathrm{~m}){ }^{*},{ }^{* *}$ and ${ }^{* * *}$ indicate significant difference with control plots with no $\mathrm{N}$ addition at $P<0.05$, $P<0.01$ and $P<0.001$. Data are mean $\pm \mathrm{SE}(n=8)$.

with an increase in $\mathrm{N}$ addition rate $(P=0.018$, Fig. $1 \mathrm{~d})$. These results indicate that the reduction in total species richness by $\mathrm{N}$ addition is mainly accounted for by loss of forb species.

\section{2 $\mathrm{N}$ addition acidified soil and increased inorganic $\mathrm{N}$ and $P$ availability}

Soil $\mathrm{pH}$ was significantly reduced with increase of $\mathrm{N}$ addition rates, such that $\mathrm{N}$ addition rate at $16(P<0.0001)$ and $32 \mathrm{~g} \mathrm{~N} \mathrm{~m}^{-2} \mathrm{yr}^{-1}(P<0.0001)$ reduced soil $\mathrm{pH}$ from 6.82 to 6.29 and 5.37, respectively (Fig. 2). Soil inorganic$\mathrm{N}$ concentrations were significantly increased by $\mathrm{N}$ addition rate greater than $8 \mathrm{~g} \mathrm{~N} \mathrm{~m}^{-2} \mathrm{yr}^{-1}(P=0.006$, Fig. 3a). There was a significantly positive correlation $(r=0.86$, $P<0.001$ ) between inorganic $\mathrm{N}$ (IN) and $\mathrm{N}$ addition rate (Table A1). A significant increase $(P=0.030)$ in soil available $\mathrm{P}$ (Olsen-P) was detected at high doses of $\mathrm{N}$ addition $\left(>16 \mathrm{~g} \mathrm{~N} \mathrm{~m}^{-2} \mathrm{yr}^{-1}\right)$, whereas soil Olsen-P was not affected by low doses of $\mathrm{N}$ addition (Fig. 3a). The results of linear regression showed that inorganic $\mathrm{N}$ and Olsen-P in soil were linearly correlated with AGB (IN: $r=-0.486, P<0.0001$; Olsen-P: $r=-0.435, P=0.002)$ and forb species richness (IN: $r=-0.521, P<0.0001$; Olsen-P: $r=-0.338$, $P=0.019$ ) (Table A2). Soil $\mathrm{pH}$ was also linearly correlated with AGB $(r=0.437, P=0.002)$, forb richness $(r=0.699$, $P<0.0001)$ and graminoid richness $(r=0.415, P=0.003)$ (Table A2). These results indicate that soil $\mathrm{pH}$, Olsen-P and inorganic- $\mathrm{N}$ concentrations play important roles in the $\mathrm{N}$ addition-induced changes in AGB and species richness. 


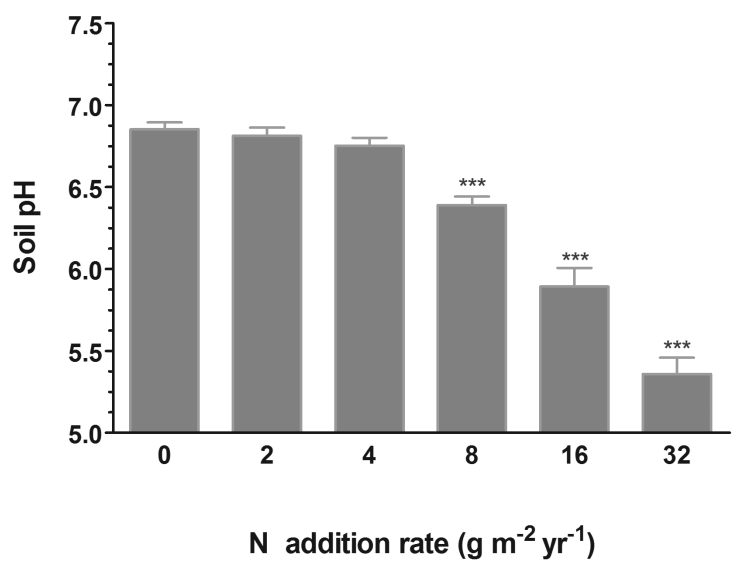

Figure 2. Reduction of soil $\mathrm{pH}$ with $\mathrm{N}$ addition rate. Soil $\mathrm{pH}$ was measured after $\mathrm{N}$ addition for 9 years. ANOVA analysis with Duncan's test was used to determine the significance. ${ }^{* * *}$ indicates significant difference with control plots at $P<0.001$. Data are mean $\pm \operatorname{SE}(n=8)$.

\section{3 $\mathrm{N}$ addition-induced soil acidification altered availabilities of metal elements}

EC of soil is an indicator to reflect exchangeable ion concentrations in soil (Friedman, 2005). $\mathrm{N}$ addition caused a significant increase in soil EC (Fig. A1), indicating that $\mathrm{N}$ addition may lead to solubilization of some ions from soil minerals. Calcium $\left(\mathrm{Ca}^{2+}\right)$, magnesium $\left(\mathrm{Mg}^{2+}\right)$ and potassium $\left(\mathrm{K}^{+}\right)$are main base cations in soils of calcareous and alkaline grasslands. $\mathrm{N}$ addition across the rates used in the present study generally led to significant decline in these cation concentrations (Fig. 3b). A negatively significant correlation existed between $\mathrm{N}$ addition rates and concentrations of $\mathrm{Ca}^{2+}$ and $\mathrm{Mg}^{2+}$ (Table A1). The positive correlation of $\mathrm{Ca}^{2+}$ and $\mathrm{Mg}^{2+}$ with soil $\mathrm{pH}$ indicates that soil acidification is likely to be a key cause for the reduction in soil $\mathrm{Ca}^{2+}$ and $\mathrm{Mg}^{2+}$. In contrast to the base cations, $\mathrm{N}$ addition resulted in significant increases in availabilities of several metal ions, such as iron $\left(\mathrm{Fe}^{3+}\right)$, manganese $\left(\mathrm{Mn}^{2+}\right)$, copper $\left(\mathrm{Cu}^{2+}\right)$ and aluminum $\left(\mathrm{Al}^{3+}\right)$ (Fig. 3c). $\mathrm{N}$ addition-induced increases in soil $\mathrm{Fe}^{3+}$ and $\mathrm{Mn}^{2+}$ concentrations were most evident compared to other metal ions (Fig. 3c). Moreover, concentrations of $\mathrm{Fe}^{3+}, \mathrm{Mn}^{2+}, \mathrm{Cu}^{2+}$ and $\mathrm{Al}^{3+}$ showed positive and negative response to $\mathrm{N}$ addition and soil $\mathrm{pH}$, respectively (Table $\mathrm{A} 1$ ). These results suggest that $\mathrm{N}$ addition-induced soil acidification is a driver for mobilization of these metal cations. Concentrations of $\mathrm{K}^{+}$and $\mathrm{Zn}^{2+}$ exhibited no significant correlation with $\mathrm{N}$ addition rates and soil $\mathrm{pH}$ (Table A1). These results rule out the possibility that changes in soil $\mathrm{K}^{+}$and $\mathrm{Zn}^{2+}$ concentrations may contribute to the decline in plant species richness induced by $\mathrm{N}$ deposition. Therefore, concentrations of $\mathrm{K}^{+}$and $\mathrm{Zn}^{2+}$ were not included in the following linear regression and PCA.
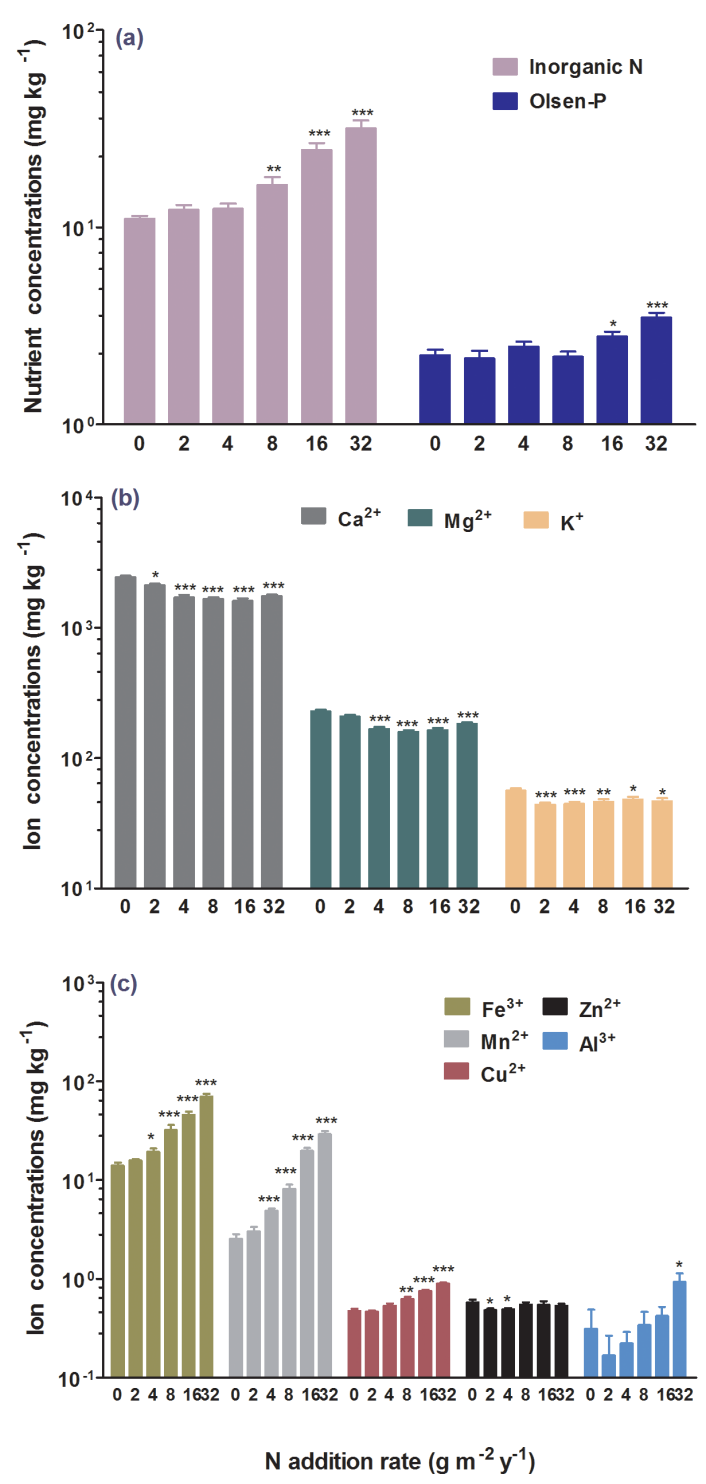

Figure 3. Effect of $\mathrm{N}$ addition on exchangeable ion concentrations in soils. Data are mean $\pm \operatorname{SE}(n=8) .{ }^{*},{ }^{*}$ and ${ }^{* * *}$ indicate significant difference between control (no $\mathrm{N}$ added) and $\mathrm{N}$-added plots at $P<0.05, P<0.01$ and $P<0.001$, respectively.

\subsection{Concentrations of metal ions in soil were correlated with AGB and species richness}

To test whether the soil acidification-driven changes in soil metal ions are involved in decline in species richness under $\mathrm{N}$-added regimes, correlations among element availabilities, AGB and species richness of forbs and graminoids were explored. A negatively linear relationship between four soil nutrients $\left(\mathrm{Fe}^{3+}\right.$, $\left.\mathrm{Mn}^{2+}, \mathrm{Cu}^{2+}, \mathrm{Al}^{3+}\right)$ and forb AGB $\left(\mathrm{Fe}^{3+}: R^{2}=0.13\right.$, $P=0.0111 ; \quad \mathrm{Mn}^{2+}: \quad R^{2}=0.21, \quad P=0.0010 ; \quad \mathrm{Cu}^{2+}$ : $\left.R^{2}=0.16, \quad P=0.0044 ; \quad \mathrm{Al}^{3+}: \quad R^{2}=0.22, \quad P=0.0007\right)$ and species richness $\left(\mathrm{Fe}^{3+}: R^{2}=0.32, P<0.0001 ; \mathrm{Mn}^{2+}\right.$ : 

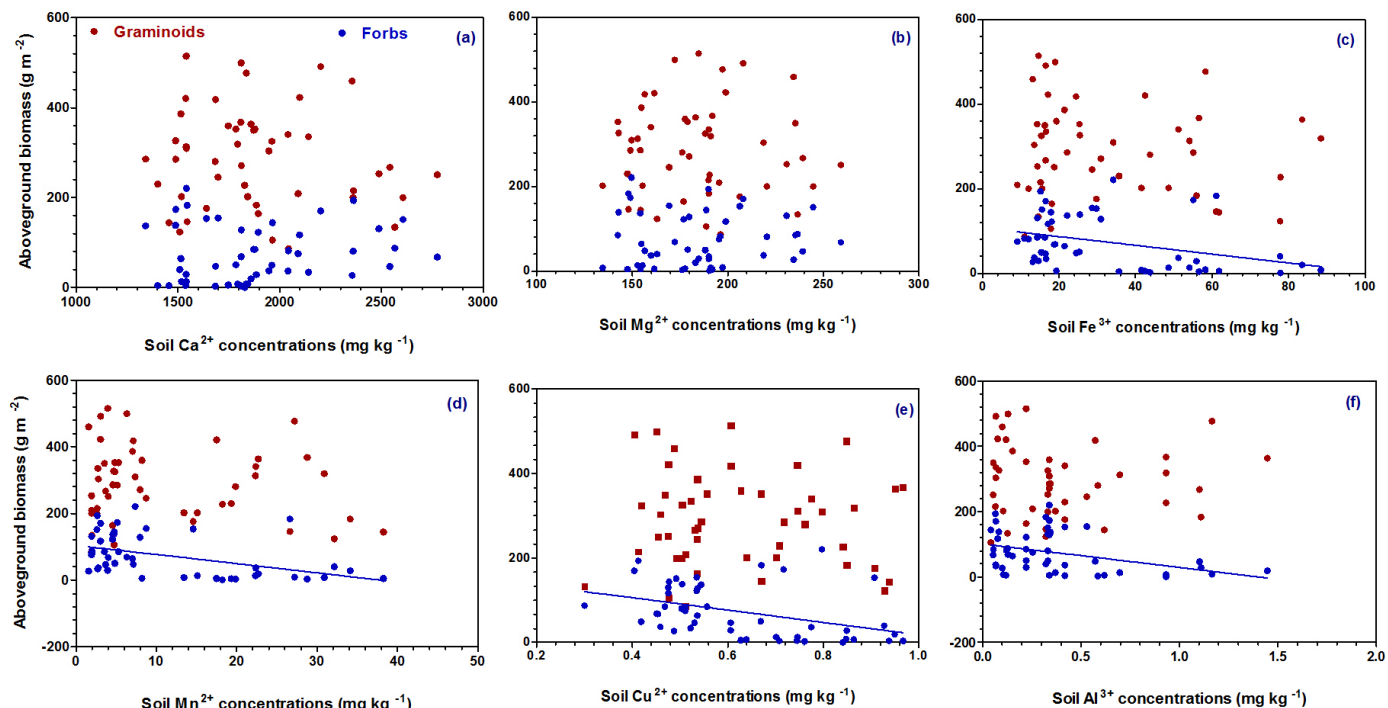

Figure 4. Correlation of metal ion concentrations in soil and aboveground biomass (AGB) of graminoids and forbs. Filled circles and open circles respectively corresponded to forbs and graminoids. Linear regression was used to identify the significance of the correlation between soil ions and AGB. $\mathrm{Fe}^{3+}\left(R^{2}=0.13, P=0.0111\right), \mathrm{Mn}^{2+}\left(R^{2}=0.21, P=0.0010\right), \mathrm{Cu}^{2+}\left(R^{2}=0.16, P=0.0044\right)$ and $\mathrm{Al}^{3+}\left(R^{2}=0.22\right.$, $P=0.0007)$ showed linear correlation with AGB of forbs.
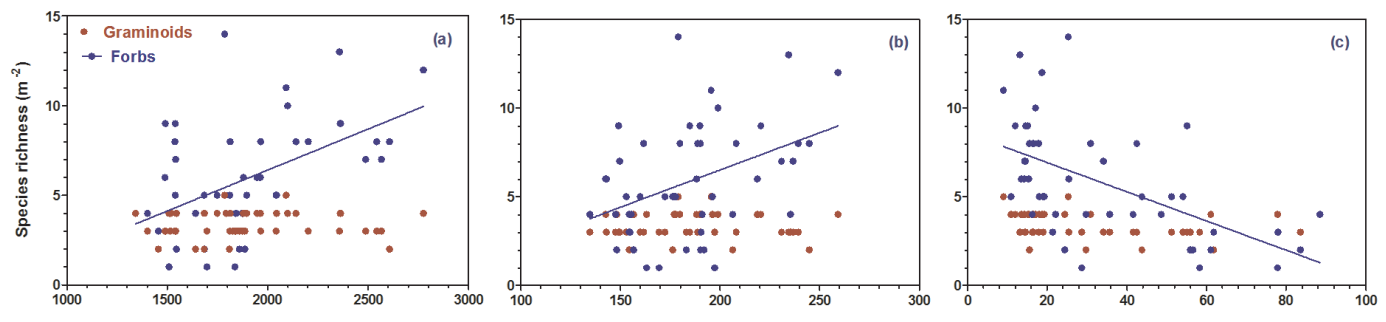

Soil $\mathrm{Ca}^{2+}$ concentrations $\left(\mathrm{mg} \mathrm{kg}^{-1}\right)$

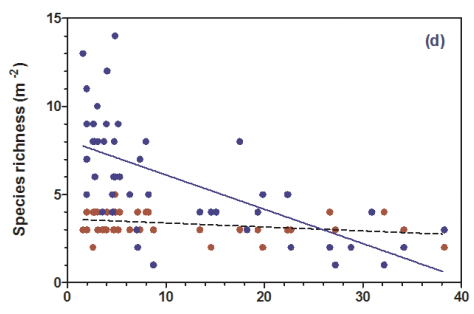

Soil $\mathrm{Mg}^{2+}$ concentrations $\left(\mathrm{mg} \mathrm{kg}^{-1}\right.$ )

Soil $\mathrm{Fe}^{3+}$ concentrations $\left(\mathrm{mg} \mathrm{kg}^{-1}\right.$ )

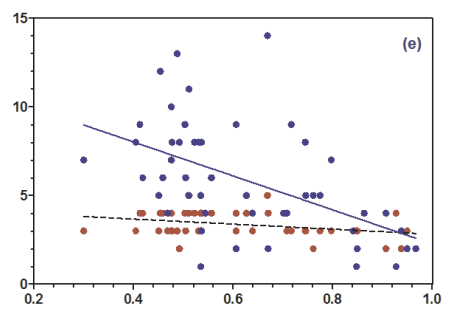

Soil $\mathrm{Cu}^{2+}$ concentrations $\left(\mathrm{mg} \mathrm{kg}^{-1}\right.$ )

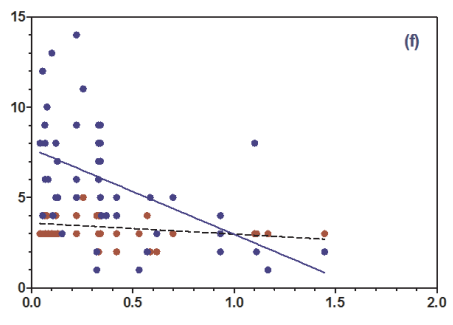

Soil $\mathbf{A l}^{3+}$ concentrations $\left(\mathrm{mg} \mathrm{kg}^{-1}\right.$ )

Figure 5. Correlation of ion concentrations in soil and species richness of graminoids and forbs. Filled circles corresponded to forbs and open circles corresponded to graminoids. Linear regression was used to identify the significance of the correlation between soil ions and species richness. Solid lines and dotted lines are the forbs and graminoids fit with the model. $\mathrm{Ca}^{2+}\left(R^{2}=0.26, P=0.0002\right)$, $\mathrm{Mg}^{2+}\left(R^{2}=0.17, P=0.0038\right), \mathrm{Fe}^{3+}\left(R^{2}=0.32, P<0.0001\right), \mathrm{Mn}^{2+}\left(R^{2}=0.41, P<0.0001\right), \mathrm{Cu}^{2+}\left(R^{2}=0.27, P=0.0002\right)$ and $\mathrm{Al}^{3+}$ $\left(R^{2}=0.30, P<0.0001\right)$ showed linear correlation with species richness of forbs.

$R^{2}=0.41, \quad P<0.0001 ; \quad \mathrm{Cu}^{2+}: \quad R^{2}=0.27, \quad P=0.0002 ;$ $\left.\mathrm{Al}^{3+}: R^{2}=0.30, P<0.0001\right)$ was observed (Figs. 4 and 5). Soil $\mathrm{Ca}^{2+}\left(R^{2}=0.26, P=0.0002\right)$ and $\mathrm{Mg}^{2+}\left(R^{2}=0.17\right.$, $P=0.0038$ ) only exhibited positive correlation with forb species richness (Fig. 5). In contrast, both richness and AGB for graminoids were not affected by the majority of metal ions, with their AGB showing no significant correlation with these ions and their species richness exhibiting negative correlation with $\mathrm{Mn}^{2+}, \mathrm{Cu}^{2+}$ and $\mathrm{Al}^{3+}$ concentrations (Figs. 4 and 5).

\subsection{Principle component analysis}

Based on the results of linear regression (Table A1), the six metal cations $\left(\mathrm{Ca}^{2+}, \mathrm{Mg}^{2+}, \mathrm{Mn}^{2+}, \mathrm{Fe}^{3+}, \mathrm{Cu}^{2+}, \mathrm{Al}^{3+}\right)$ that 
Table 1. Factor loadings of six mineral nutrient variables on axes 1 and 2 of the principal components analysis.

\begin{tabular}{lrr}
\hline Variables & Factor 1 & Factor 2 \\
\hline $\mathrm{Fe}^{3+}$ & 0.882 & -0.264 \\
$\mathrm{Mn}^{2+}$ & 0.938 & -0.227 \\
$\mathrm{Cu}^{2+}$ & 0.880 & -0.318 \\
$\mathrm{Al}^{3+}$ & 0.898 & -0.058 \\
$\mathrm{Ca}^{2+}$ & -0.284 & 0.910 \\
$\mathrm{Mg}^{2+}$ & -0.137 & 0.951 \\
\hline
\end{tabular}

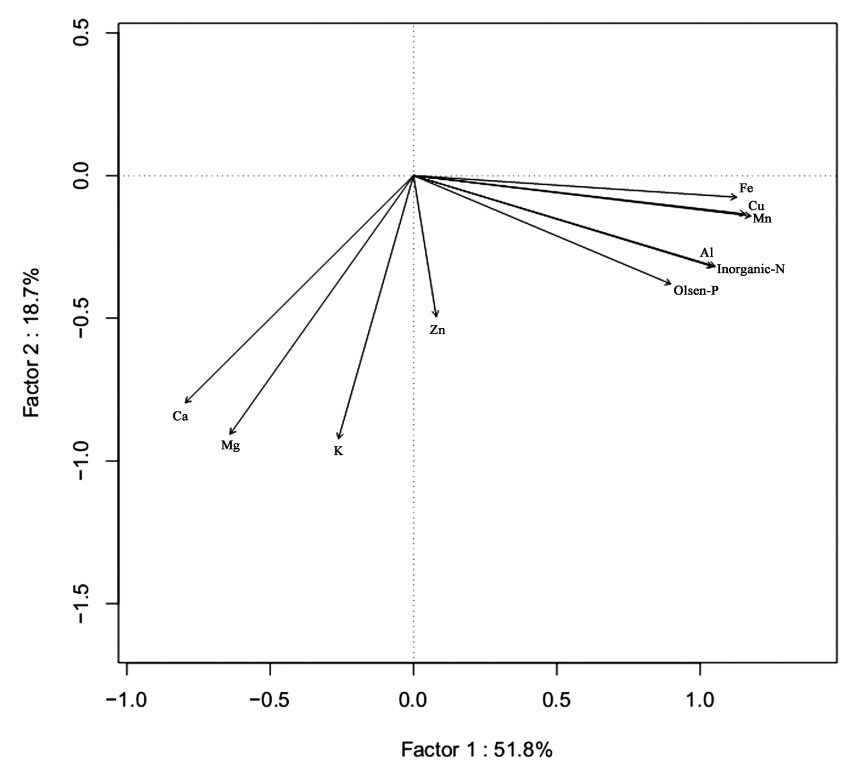

Figure 6. Projection of six elemental variables for principle component analysis factors one and two.

were significantly correlated with soil $\mathrm{pH}$ were used for the PCA analysis. Principle components analysis gave two axes of variation with eigenvalues greater than 1 , accounting for a total of $88.28 \%$ of the variation in six metal ion variables (Fig. 6). The first principal component (PC1) based on strong positive loadings on axis 1 (Table 1) included $\mathrm{Mn}^{2+}, \mathrm{Cu}^{2+}$, $\mathrm{Fe}^{3+}$ and $\mathrm{Al}^{3+}$ which explained $66.7 \%$ of the variation (eigenvalues $=4.004)$. Linear regression showed that this group had significant correlation with soil $\mathrm{pH}(P<0.001)$, indicating that $\mathrm{PC} 1$ is a mainly $\mathrm{pH}$-dependent metal ion (Table A1). PC1 reflected the release potential of microelements (Table 1). Due to higher loadings on axis $2, \mathrm{Ca}^{2+}$ and $\mathrm{Mg}^{2+}$ were clustered into the second principal component (PC2), accounting for $21.6 \%$ of the variation (eigenvalues =1.293) (Fig. 6). $\mathrm{Ca}^{2+}$ and $\mathrm{Mg}^{2+}$ were the fundamental constitutes of alkaline soils and play an important role in acid buffering; thus, the PC2 reflected the basic soil properties.

GLM was used to further assess the extent to which significant species richness and AGB are affected by principal soil ions (Table 2). Given that concentrations of inorganic N,
Olsen-P and metal cations driven by soil acidification exhibited significant correlation with AGB and species richness of forbs (Table A3 and Figs. 4, 5), inorganic N, Olsen-P and two PCA axes (F1 and F2) were included in the GLM analysis. As shown in Table 2, F1 axes that reflected the release of metal ions $\left(\mathrm{Mn}^{2+}, \mathrm{Fe}^{3+}, \mathrm{Cu}^{2+}\right.$ and $\left.\mathrm{Al}^{3+}\right)$ accounted for $42.77 \%$ of the variation in forb richness, while inorganic $\mathrm{N}$ accounted for $23.59 \%$ variation in AGB of forbs. Variation in graminoid species richness and AGB was not explained by $\mathrm{F} 1$ axes and inorganic N. Changes in the base cations (F2 PCA axes) and P availability did not contribute to AGB and species richness of forbs. Compared with inorganic-N availability, patterns in forb richness were primarily driven by changes in the heavy metal ion availabilities.

\section{Discussion}

Nitrogen deposition has multiple impacts on grassland ecosystems, including changes in productivity, reductions in species richness and soil acidification (Smith et al., 1999; Stevens et al., 2004; Galloway et al., 2008; Clark and Tilman, 2008; Bobbink et al., 2010). Elevated N deposition resulting from human activities in the past decades has negative impacts on growth and development of certain plant species, leading to reduction in plant diversity (Isbell et al., 2013; Maskell et al., 2010; Stevens et al., 2006). To evaluate the effects of $\mathrm{N}$ deposition on temperate grassland ecosystems, long-term $\mathrm{N}$ fertilization experiments were conducted in Inner Mongolia steppes by applying urea. The applied urea can be hydrolyzed to ammonia/ammonium, by the enzyme urease, and ammonium is further converted into nitrate by ammonia oxidizing bacteria and ammonia oxidizing archaea, leading to an increase in inorganic $\mathrm{N}$ in soils and concurrent reduction in soil pH (Zhang L. M. et al., 2012). Previous studies showed that the application of urea led to significant increases in soil nitrate concentrations and soil acidification (Fang et al., 2012), which are consistent with this proposition. Despite potential differences in natural $\mathrm{N}$ deposition and application of urea in terms of soil acidification and enrichment of soil $\mathrm{N}$, our $\mathrm{N}$ addition experiments can simulate the natural $\mathrm{N}$ deposition. In the present study, we found that a low and moderate rate of $\mathrm{N}$ addition for consecutive 9 years led to an enhanced total AGB (Fig. 1a). More specifically, we found that AGB of graminoids and forbs displayed different responses to $\mathrm{N}$ addition, such that AGB of graminoids and forbs was increased and relatively unchanged by moderate $\mathrm{N}$ addition, respectively (Fig. 1c). Species richness of graminoids and forbs also differed in their responses to $\mathrm{N}$ addition. $\mathrm{N}$ addition significantly reduced forb species richness, while graminoid species richness was relatively unchanged in response to the $\mathrm{N}$ addition (Fig. 1d). These findings that forbs were more sensitive to $\mathrm{N}$ deposition than graminoids in terms of species richness are consistent with the results 
Table 2. Multiple regression testing the effect of the dependent variables on species richness and biomass of forbs and Graminoids. Partial correlation coefficient, $F$ value and $P$ values are given. Variables in the regression are $F 1\left(F 1=-0.35 \times Z \mathrm{Ca}^{2+}-0.30 \times Z\right.$ $\left.\mathrm{Mg}^{2+}+0.45 \times Z \mathrm{Fe}^{3+}+0.46 \times Z \quad \mathrm{Mn}^{2+}+0.46 \times Z \quad \mathrm{Cu}^{2+}+0.40 \times Z \quad \mathrm{Al}^{3+}\right), \quad F 2 \quad\left(F 2=0.57 \times Z \quad \mathrm{Ca}^{2+}+0.67 \times Z \quad \mathrm{Mg}^{2+}+0.18 \times Z\right.$ $\left.\mathrm{Fe}^{3+}+0.24 \times Z \mathrm{Mn}^{2+}+0.14 \times Z \mathrm{Cu}^{2+}+0.35 \times Z \mathrm{Al}^{3+}\right)$, inorganic $\mathrm{N}$ and Olsen-P. $F 1$ and $F 2$ respectively represent PCA axes 1 and PCA axes 2 .

\begin{tabular}{lccc|ccc|ccccccc}
\hline Variables & \multicolumn{3}{c}{ Forb biomass } & \multicolumn{3}{c|}{ Forb richness } & \multicolumn{3}{c|}{ Graminoid biomass } & \multicolumn{3}{c}{ Graminoid richness } \\
& $p-R^{2}$ & $F$ & $P$ & $p-R^{2}$ & $F$ & $P$ & $p-R^{2}$ & $F$ & $P$ & $p-R^{2}$ & $F$ & $P$ \\
\hline F1 & 0.0003 & 0.02 & 0.9026 & 0.4277 & 34.38 & $<0.0001$ & 0.0291 & 1.39 & 0.2451 & 0.0768 & 3.83 & 0.0565 \\
F2 & 0.0116 & 0.72 & 0.4018 & 0.0003 & 0.02 & 0.8907 & 0.0124 & 0.59 & 0.4478 & 0.0580 & 3.01 & 0.0894 \\
Inorganic-N & 0.2359 & 14.20 & 0.0005 & 0.0011 & 0.08 & 0.7721 & 0.0336 & 1.60 & 0.2119 & 0.0000 & 0.00 & 0.9891 \\
Olsen-P & 0.0381 & 2.36 & 0.1312 & 0.0086 & 0.69 & 0.4106 & 0.0227 & 1.07 & 0.3071 & 0.0004 & 0.02 & 0.8918 \\
\hline
\end{tabular}

obtained in semi-natural European grasslands (Stevens et al., 2006).

Species loss induced by $\mathrm{N}$ deposition on grasslands has been suggested to result from competition due to increased growth of graminoids in response to $\mathrm{N}$ enrichment (Stevens et al., 2006). Although a moderate rate of $\mathrm{N}$ addition, i.e. 2 and $4 \mathrm{~g} \mathrm{~m}^{-2} \mathrm{yr}^{-1}$, stimulated grass growth, the total species richness and forb species richness under these $\mathrm{N}$ addition rates were relatively constant (Fig. 1). Moreover, at higher rates of $\mathrm{N}$ addition (16 and $32 \mathrm{~g} \mathrm{~m}^{-2} \mathrm{yr}^{-1}$ ), AGB of graminoids was not enhanced, but species richness of forbs was dramatically reduced (Fig. 1). These results may suggest that loss of forbs is not simply caused by competitive exclusion driven by increased growth of graminoids, rather these findings may highlight the involvement of other processes associated with $\mathrm{N}$ addition in inhibition of forb growth.

Enhanced $\mathrm{N}$ deposition may decrease plant diversity by enrichment of nitrogen nutrient (van den Berg et al., 2005; Stevens et al., 2006; Zhang et al., 2014). In our study, N addition led to significant increases in inorganic $\mathrm{N}$ in soils (Fig. 3a). Forb species richness and AGB was negatively correlated to soil inorganic-N concentration (Table A2). Moreover, inorganic $\mathrm{N}$ in soil accounted for $23.59 \%$ of the variation in forb AGB (Table 2). These results suggest that an increase in $\mathrm{N}$ availability due to $\mathrm{N}$ addition may contribute to $\mathrm{N}$ deposition-induced loss of forb species. Stevens et al. (2006) and Zhang et al. (2014) demonstrated that species richness is negatively correlated with soil $\mathrm{NH}_{4}^{+}-\mathrm{N}$ concentrations in both acidic grasslands and alkaline grasslands. Processes associated with $\mathrm{N}$ transformation in soils, including mineralization and nitrification, depend on soil $\mathrm{pH}$, which determine homeostasis of $\mathrm{NH}_{4}^{+}-\mathrm{N}$ and $\mathrm{NO}_{3}-\mathrm{N}$ (Dorland et al., 2004). Although it has been reported that species from acidic and alkaline soils usually prefer different forms of nitrogen (Falkengren-Grerup and Lakkenborg-Kristensen, 1994; van den Berg et al., 2005), both high $\mathrm{NO}_{3}^{-}-\mathrm{N}$ concentration and high $\mathrm{NH}_{4}^{+}-\mathrm{N}$ concentration can suppress root elongation (Britto and Kronzucher, 2002; Tian et al., 2005, 2009; Zhao et al., 2007). Therefore, it is necessary to further dynamically monitor changes in $\mathrm{N}$ forms in soils after $\mathrm{N}$ addition and to evaluate the different response of forbs and graminoids to different $\mathrm{N}$ forms. In addition to enrichment of $\mathrm{N}$, an increase in soil $\mathrm{P}$ availability has been implicated in the reduction of species richness of grasslands (Ceulemans et al., 2013). In the present study, $\mathrm{N}$ addition significantly increased the Olsen-P concentration in soils (Fig. 3). The increase in $\mathrm{P}$ availability may result from $\mathrm{N}$ addition-induced soil acidification because $\mathrm{P}$ is mainly precipitated as calcium phosphate in calcareous and alkalinous soil, its solubility would be enhanced by reduced soil $\mathrm{pH}$. Although Olsen-P concentration in soils exhibited negative correlation with forb species richness (Table A3), multiple regression showed that $\mathrm{P}$ availability did not contribute to the $\mathrm{N}$-induced changes in forb species richness and biomass (Table 2). These results discount the involvement of $\mathrm{P}$ availability in the $\mathrm{N}$-induced changes in species richness.

Soil acidification often concurs with $\mathrm{N}$ deposition due to the formation of hydrogen ions during ammonia oxidation (Guo et al., 2010; Y. Yang et al., 2012). Numerous studies across N deposition gradients (Maskell et al., 2010; Stevens et al., 2004) and field fertilization experiments (Bowman et al., 2008; Lan and Bai, 2012; Zhang et al., 2014) have demonstrated that $\mathrm{N}$ deposition leads to soil acidification. In the present study, we found a significant soil acidification by 9 -year $\mathrm{N}$ addition in the calcareous temperate grassland (Fig. 2). A positive correlation between soil $\mathrm{pH}$ and the species richness was found in this study (Table A2). However, Chytrý et al. (2007) reported that in tundra and forest with low soil $\mathrm{pH}$, species richness is increased with soil $\mathrm{pH}$, while in steppe with soil $\mathrm{pH}>6.0$, the species richness appears to be negatively dependent on soil $\mathrm{pH}$. The differences between our results and those of Chytrý et al. (2007) may be accounted for by the differences in soil traits because the relationship between species richness and soil $\mathrm{pH}$ is dependent upon vegetation types, soil traits and climatic conditions (Chytrý et al., 2007). Soil pH in our study was reduced from 6.82 to 5.37 by the $\mathrm{N}$ addition (Fig. 2). This $\mathrm{pH}$ range is comparable to that of forest surveyed by Chytrý et al. (2007). In this range of soil $\mathrm{pH}$, they also discovered that species richness is positively correlated with soil $\mathrm{pH}$ (Chytrý et al., 2007). Species richness showed positive correlation between 
soil $\mathrm{pH}$ suggests that soil $\mathrm{pH}$ is an important factor in determination of species richness in the Inner Mongolia steppe.

Soil acidification would disturb ion homeostasis in soil, including depletion of base cations and mobilization of metal cations (Bowman et al., 2008; Horswill et al., 2008). $\mathrm{Ca}^{2+}$, $\mathrm{Mg}^{2+}$ and $\mathrm{K}^{+}$are dominant base cations in calcareous soils. Depletion of these base cations in soils by $\mathrm{N}$ addition (Fig. 3b) would render the soil less capable of buffering acid. The insignificant correlation between $\mathrm{K}^{+}$concentrations and soil $\mathrm{pH}$, and $\mathrm{N}$ addition rates rules out the possibility that soil $\mathrm{K}^{+}$may contribute to the decline in plant diversity (Table A1). Multiple regression showed that changes in $\mathrm{Ca}^{2+}$ and $\mathrm{Mg}^{2+}$ concentrations reflected by $\mathrm{F} 2$ contributed little to AGB and species richness of forbs, suggesting that patterns in species richness of forbs are not driven by depletion of $\mathrm{Ca}^{2+}$ and $\mathrm{Mg}^{2+}$ induced by $\mathrm{N}$ addition.

In addition to depletion of base cations, soil acidification can release some metal ions by increasing their solubility. $\mathrm{N}$ addition markedly enhanced concentrations of $\mathrm{Mn}^{2+}$, $\mathrm{Fe}^{3+}, \mathrm{Cu}^{2+}$ and $\mathrm{Al}^{3+}$ in soils (Fig. 3c), and changes in these metal ions explained more variation on forb species richness than inorganic-N (Table 2). These results suggest that the release of metal cations is a main driving force for $\mathrm{N}$ addition-evoked loss of forb species. In contrast to $\mathrm{Mn}^{2+}$, $\mathrm{Fe}^{3+}$ and $\mathrm{Cu}^{2+}$, an increase in soil $\mathrm{Al}^{3+}$ concentration was not detected with $\mathrm{N}$ addition rate $<32 \mathrm{~g} \mathrm{~m}^{-2} \mathrm{yr}^{-1}$ (Fig. 3c), while loss of forb species had already occurred at moderate $\mathrm{N}$ addition rate $\left(8 \mathrm{~g} \mathrm{~m}^{-2} \mathrm{yr}^{-1}\right)$ (Fig. 1d). These results may imply that soil $\mathrm{Al}^{3+}$ is unlikely to be a key driving factor for species loss evoked by $\mathrm{N}$ deposition in our experimental systems. Several studies have demonstrated that Al toxicity is involved in $\mathrm{N}$ deposition-induced species loss in acidic grasslands with soil $\mathrm{pH}<5$ (Stevens et al., 2009). In our studies, soil $\mathrm{pH}$ was greater than 5 even under the highest $\mathrm{N}$ addition rates (Fig. 2). Moreover, changes in $\mathrm{Al}^{3+}$ concentration had lower partial correlation coefficient $\left(p-R^{2}\right)$ with soil $\mathrm{pH}$ (Table A3). Given that Al phytoxcity normally occurs at soil $\mathrm{pH}<5$ (Tyler, 1996), the contribution of Al toxicity to species loss can be discounted in our studies. Similar to results reported by Bowman et al. (2008), we found that $\mathrm{N}$ addition led to a substantial increase in soil $\mathrm{Fe}^{3+}$ concentration.
Because forbs can only take up $\mathrm{Fe}^{2+}$ after reduction of $\mathrm{Fe}^{3+}$ to $\mathrm{Fe}^{2+}$ by ferric chealate reductases in roots (Marschner, 1995 ), the $\mathrm{N}$ addition-induced increase in soil $\mathrm{Fe}^{3+}$ concentration would contribute little to the loss of forb species in the present study. Based on the results of linear regression analyses, compared with $\mathrm{Cu}^{2+}, \mathrm{Mn}^{2+}$ exhibited the closest correlation with soil $\mathrm{pH}$ and $\mathrm{Mn}^{2+}$ concentrations were most greatly affected by $\mathrm{N}$ addition (Fig. 3, Table A1). Therefore, mobilization of $\mathrm{Mn}^{2+}$ due to soil acidification induced by $\mathrm{N}$ addition is expected to be a critical process responsible for forbs loss in the Inner Mongolia steppe under elevated $\mathrm{N}$ deposition, because availability of ions in soil affects nutrient uptake of plants (Marschner, 1995). Forb species would be more prone to accumulate $\mathrm{Mn}$ than graminoid species because of their intrinsic differences in biochemical pathways to regulate metal transport (Marschner, 1995). Therefore, further studies to evaluate the effects of $\mathrm{N}$ addition on accumulation of metals in general and $\mathrm{Mn}$ in particular by forbs and graminoids would provide a biochemical explanation for loss of forb species in the steppe under elevated $\mathrm{N}$ deposition.

\section{Conclusions}

We demonstrate that $\mathrm{N}$ addition reduced species richness, acidified soil and disturbed nutrient homeostasis in soil in an Inner Mongolia steppe. We further reveal that decline in species richness by $\mathrm{N}$ addition was mainly accounted for by loss of forb species as forbs were more sensitive to $\mathrm{N}$ addition than graminoids. Our findings also show that $\mathrm{N}$ addition resulted in an increase in inorganic- $\mathrm{N}$ concentration, depletion of base cations $\left(\mathrm{Ca}^{2+}\right.$ and $\left.\mathrm{Mg}^{2+}\right)$ and mobilization of $\mathrm{Mn}^{2+}$ ions. Nitrogen availability and release of $\mathrm{Mn}^{2+}$ ions were involved in changes of biomass and diversity in the temperate steppe. These findings highlight that soil acidificationmediated $\mathrm{Mn}^{2+}$ mobilization is a key factor to drive decline in the species richness of forbs under elevated $\mathrm{N}$ addition in the alkaline, calcareous grasslands in northern China. 


\section{Appendix A}

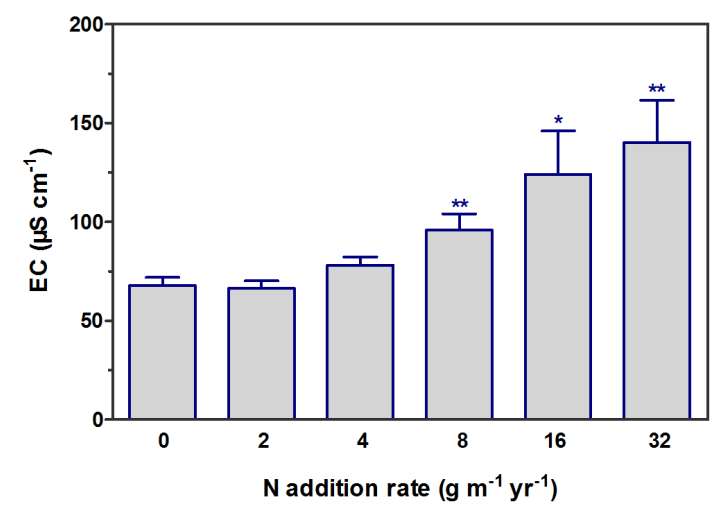

Figure A1. Effect of $\mathrm{N}$ addition on soil electrical conductivity. Data are mean $\pm \operatorname{SE}(n=8) .{ }^{*}$ and ${ }^{* *}$ respectively indicate significant difference between control (no $\mathrm{N}$ added) and $\mathrm{N}$-added plots at $P<0.05$ and $P<0.01$.

Table A1. Pearson correlation coefficients $(r)$ between ion concentrations and $\mathrm{N}$ addition rate and soil $\mathrm{pH}(r>0$ indicates positive correlations, $r<0$ indicates negative correlations).

\begin{tabular}{|c|c|c|c|c|c|c|c|c|c|c|c|c|}
\hline \multirow[t]{2}{*}{ Variables } & \multicolumn{3}{|c|}{ Forb biomass } & \multicolumn{3}{|c|}{ Forb richness } & \multicolumn{3}{|c|}{ Graminoids biomass } & \multicolumn{3}{|c|}{ Graminoids richness } \\
\hline & $r$ & $F$ & $P$ & $r$ & $F$ & $P$ & $r$ & $F$ & $P$ & $r$ & $F$ & $P$ \\
\hline Inorganic-N & -0.486 & 14.203 & 0.000 & -0.521 & 17.147 & 0.000 & 0.066 & 0.204 & 0.654 & -0.276 & 3.798 & 0.057 \\
\hline Olsen-P & -0.435 & 10.756 & 0.002 & -0.338 & 5.916 & 0.019 & -0.151 & 1.066 & 0.307 & -0.261 & 3.362 & 0.073 \\
\hline Soil $\mathrm{pH}$ & 0.437 & 10.885 & 0.002 & 0.699 & 43.875 & 0.000 & 0.078 & 0.278 & 0.600 & 0.415 & 9.556 & 0.003 \\
\hline
\end{tabular}

*, ** and $* * *$ indicate the correlation is significant at $P<0.05, P<0.01$ and $P<0.001$.

Table A2. Linear regression between inorganic $\mathrm{N}$, soil $\mathrm{pH}$ and Olsen-P with forb biomass, forb richness, graminoid biomass and graminoid richness. Pearson correlation coefficient $(r), F$ value and $P$ values are given. $r>0$ indicates positive correlations, $r<0$ indicates negative correlations.

\begin{tabular}{lrrrrrrrrrr}
\hline Dependent variables & Inorganic N & Olsen-P & $\mathrm{Ca}^{2+}$ & $\mathrm{Mg}^{2+}$ & $\mathrm{K}^{+}$ & $\mathrm{Fe}^{3+}$ & $\mathrm{Mn}^{2+}$ & $\mathrm{Cu}^{2+}$ & $\mathrm{Zn}^{2+}$ & $\mathrm{Al}^{3+}$ \\
\hline $\mathrm{N}$ addition & $0.86^{* * *}$ & $0.69^{* * *}$ & $-0.46^{* *}$ & $-0.31^{*}$ & -0.11 & $0.92^{* * *}$ & $0.94^{* * *}$ & $0.90^{* * *}$ & 0.06 & $0.74^{* * *}$ \\
Soil pH & $-0.77^{* * *}$ & $-0.61^{* * *}$ & $0.46^{* * *}$ & $0.35^{*}$ & 0.06 & $-0.85^{* * *}$ & $-0.92^{* * *}$ & $-0.85^{* * *}$ & -0.03 & $-0.73^{* * *}$ \\
\hline
\end{tabular}


Table A3. A list of plant species in the steppe community used in this study.

\begin{tabular}{llll}
\hline & Species & Family & Class \\
\hline Graminoids & Stipa krylovii & gramineae & monocot \\
& Cleistogenes squarrosa & gramineae & monocot \\
& Leymus chinensis & gramineae & monocot \\
& Agropyron cristatum & gramineae & monocot \\
& Poa pratensis & gramineae & monocot \\
& Koeleria cristata & gramineae & monocot \\
\hline Forbs & Artemisia frigida & compositae & dicot \\
& Potentilla acaulis & rosaceae & dicto \\
& Potentilla tanacetifolia & rosaceae & dicot \\
& Dianthus chinensis & caryophyllaceae & dicot \\
& Heteropappus altaicus & & dicot \\
Allium bidentatum & monocot \\
Melilotoides ruthenica & asteraceae & dicot \\
& Potentilla bifurca & liliaceae & dicot \\
Allium tenuissimum & leguminosae & monocot \\
& rosaceae & \\
& Carex korshinskyi & liliaceae & monocot \\
& cyperaceae & \\
\hline
\end{tabular}


Author contributions. Q.-Y. Tian, L.-H. Li, W.-M. Bai and W.H. Zhang designed the experiments and Q.-Y. Tian., N.-N. Liu, W.M. Bai and W.-H. Zhang conducted the experiments. Q.-Y. Tian and W.-H. Zhang prepared the manuscript with contributions from all co-authors.

Acknowledgements. This study is supported by National Natural Science Foundation of China (31272234 and 31470466).

Edited by: Z. Jia

\section{References}

Bai, Y., Wu, J., and Clark, C. M.: Tradeoffs and thresholds in the effects of nitrogen addition on biodiversity and ecosystem functioning: evidence from inner Mongolia Grasslands, Glob. Change Biol., 16, 358-372, 2010.

Bobbink, R., Hornung, M., and Roelofs, J. G. M.: The effects of air-borne nitrogen pollutants on species diversity in natural and semi-natural European vegetation, J. Ecol., 86, 717-738, 1998.

Bobbink, R., Hicks, K., Galloway, J., Spranger, T., Alkemade, R., Ashmore, M., Bustamante, M., Cinde, S., Davidson, E., Dentener, F., Emmett, B., Erisman, J.-W., Fenn, M., Gilliam, F., Nordin, A., Pardo, L., and de Vries, W.: Global assessment of nitrogen deposition effects on terrestrial plant diversity: a synthesis, Ecol. Appl., 20, 30-59, 2010.

Borer, E. T., Seabloom, E. W., Gruner, D. S., Harpole, W. S., Hillebrand, H., Lind, E. M., Adler, P. B., Alberti, J., Anderson, T. M., Bakker, J. D., Biederman, L., Blumenthal, D., Brown, C. S., Brudvig, L. A., Buckley, Y. M., Cadotte, M., Chu, C., Cleland, E. E., Crawley, M. J. Daleo, P., Damschen, E. I., Davies, K. F., DeCrappeo, N. M., Du, G., Firn, J., Hautier, Y., Heckman, R. W., Hector, A., HilleRisLambers, J., Iribarne, J., Klein, J. A., Knops, J. M. H., La Pierre, K. J., Leakey, A. D. B., Li, W., MacDougall, A. S., McCulley, R. L., Melbourne, B. A., Mitchell, C. E., Moore, J. L., Mortensen, B., O’Halloran, L. R., Orrock, J. L., Pascual, J., Prober, S. M., Pyke, D. A., Risch, A. C., Schuetz, M., Smith, M. D., Stevens, C. J., Sullivan, L. L., Williams, R. J., Wragg, P. D., Wright, J. P., and Yang, L. H.: Herbivores and nutrients control grassland plant diversity via light limitation, Nature, 508, 517520, 2014

Bowman, W. D., Cleveland, C. C., Halada, L., Hreško, J., and Baron, J. S.: Negative impact of nitrogen deposition on soil buffering capacity, Nat. Geosci., 1, 767-770, 2008.

Britto, D. T. and Kronzucker, H. J.: $\mathrm{NH}_{4}^{+}$toxicity in higher plants: a critical review, J. Plant Physiol., 159, 567-584, 2002.

Canfield, D. E., Glazer, A. N., and Falkowski, P. G.: The evolution and future of earth's nitrogen cycle, Science, 330, 192-196, 2010.

Cardinale, B. J., Duffy, J. E., and Gonzalez, A.: Biodiversity loss and its impact on humanity, Nature, 486, 59-67 2012.

Carnol, M., Ineson, P., and Dickinson, A. L.: Soil solution nitrogen and cations influenced by $\left(\mathrm{NH}_{4}\right)_{2} \mathrm{SO}_{4}$ deposition in a coniferous forest, Environ. Pollut., 97, 1-10, 1997.

Ceulemans, T., Merckx, R., Hens. M., and Honnay, O.: Plant species loss from European semi-natural grasslands following nutrient enrichment - is it nitrogen or is it phosphorus?, Global Ecol. Biogeogr., 22, 73-82, 2013.

Chen, D., Lan, Z., Bai, X., Grace, J. B., and Bai, Y.: Evidence that acidification-induced declines in plant diversity and productivity are mediated by changes in below-ground communities and soil properties in a semi-arid steppe, J. Ecol., 101, 1322-1334, 2013.

Chytrý, M., Danihelka, J., Ermakov, N. Hájeket, M., Hájková, P., Koçí, M., Kubesová, S., Lustyk, P., Otypková, Z., Popov, D., Roleçek, J., Rezníçková, M., Smarda, P., and Valachovi, M.: Plant species richness in continental southern Siberia: effects of $\mathrm{pH}$ and climate in the context of the species pool hypothesis, Global Ecol. Biogeogr., 16, 668-678, 2007.

Clark, C. M. and Tilman, D.: Loss of plant species after chronic low-level nitrogen deposition to prairie grasslands, Nature, 451 , 712-715, 2008.

De Schrijver, A., Verheyen, K., Mertens, J., Staelens, J., Wuyts, K., and Muys, B.: Nitrogen saturation and net ecosystem production, Nature, 451, E1-E4, 2008

Dean, S. L., Farrer, E. C., Taylor, D. L., Porras-Alfaro, A., Suding, K. N., and Sinsabaugh, R. L.: Nitrogen deposition alters plantfungal relationships: linking belowground dynamics to aboveground vegetation change, Mol. Ecol., 23, 1364-1378, 2014.

Dickson, T. L. and Foster, B. L.: Fertilization decreases plant biodiversity even when light is not limiting, Ecol. Lett., 14, 380-388, 2011.

Dorland, E, van den Berg, L. J. L., van den Berg, A. J., Vermeer, M. L., Roelofs, J. G. M., and Bobbink, R.: The effects of sod cutting and additional liming on potential net nitrification in heathland soils, Plant Soil, 265, 267-277, 2004.

Dupre, C., Stevens, C. J., Ranke, T., Bleerker, A., Peppler-Lisbach, C., Gowing, D. J. G., Dise, N. B., Dorland, E., Bobbink, R., and Diekmann, M.: Changes in species richness and composition in European acidic grasslands over the past 70 years: the contribution of cumulative atmospheric nitrogen deposition, Glob. Change Biol., 16, 344-357, 2010.

Falkengren-Grerup, U. and Lakkenborg-Kristensen, H.: Importance of ammonium and nitrate to the performance of herb-layer species from deciduous forests in southern Sweden, Environ. Exp. Bot., 34, 31-38, 1994.

Fang, Y., Xun, F., Bai, W., Zhang, W., and Li, L.: Long-term nitrogen addition leads to loss of species richness due to litter accumulation and soil acidification in a temperate steppe, PLoS One, 7, e47369, doi:10.1371/journal.pone.0047369, 2012.

Friedman, S. P.: Soil properties influencing apparent electrical conductivity: a review, Comput. Electron. Agri., 46, 45-70, 2005.

Galloway, J. N., Townsend, A. R., Erisman, J. W., Bekunda, M., Cai, Z. C., Freney, J. R., Martinelli, L. A., Seitzinger, S. P., and Sutton, M. A.: Transformation of the nitrogen cycle: recent trends, questions, and potential solutions, Science, 320, 889-892, 2008.

Guo, J. H., Liu, X. J., Zhang, Y., Shen, J. L., Han, W. X., Zhang, W. F., Christie, P., Goulding, K. W. T., Vitousek, P. M., and Zhang, F. S.: Significant acidification in major Chinese croplands, Science, 327, 1008-1010, 2010

Hautier, Y., Niklaus, P. A., and Hector, A.: Competition for light causes plant biodiversity loss after eutrophication, Science, 324, 636-638, 2009.

Heil, G. W. and Diemont, W. H.: Raised nutrient levels change heathland into grassland, Vegetatio, 53, 113-120, 1983. 
Horswill, P., O’Sullivan, O., Phoenix, G. K., Lee, J. A., and Leake, J. R.: Base cation depletion, eutrophication and acidification of species-rich grasslands in response to long-term simulated nitrogen deposition, Environ. Pollut., 155, 336-349, 2008.

Hou, X. Y.: Vegetation Geography of China and Chemical Composition of Dominant Species, Sciense Press, Beijing, 1982.

Houdijk, A. L. F. M., Verbeek, P. J. M., Van Dijk, H. F. G., and Roelofs, J. G. M.: Distribution and decline of endangered herbaceous heathland species in relation to the chemical composition of the soil, Plant Soil, 148, 137-143, 1993.

Isbell, F., Reich, P. B., Tilman, D., Hobbie, S. E., Polasky, S., and Binder, S.: Nutrient enrichment, biodiversity loss, and consequent declines in ecosystem productivity, P. Natl. Acad. Sci. USA, 110, 11911-11916, 2003.

Jia, Y., Yu, G., He, N., Zhan, X., Fang, H., Sheng, W., Zuo, Y., Zhang, D., and Wang, Q: Spatial and decadal variations in inorganic nitrogen wet deposition in China induced by human activity, Sci. Reports, 4, 3763, doi:10.1038/srep03763, 2014.

Jiang, C., Yu, G., Fang, H., Cao, G., and Li, Y.: Short-term effect of increasing nitrogen deposition on $\mathrm{CO}_{2}, \mathrm{CH}_{4}$ and $\mathrm{N}_{2} \mathrm{O}$ fluxes in an alpine meadow on the Qinghai-Tibetan Plateau, China Atmos. Environ., 44, 2920-2926, 2010.

Kim, T. W., Lee, K., Najjar, R. G., Jeong, H. D., and Jeong, H. J.: Increasing $\mathrm{N}$ abundance in the northwestern Pacific Ocean due to atmospheric nitrogen deposition, Science, 334, 505-509, 2011.

Kochian, L. V.: Cellular mechanisms of aluminum toxicity and resistance in plants, Annu. Rev. Plant Phys., 46, 237-260, 1995.

Lan, Z. C. and Bai, Y. F.: Testing mechanisms of N-enrichment induced species loss in a semiarid Inner Mongolia grassland: critical thresholds and implications for long-term ecosystem responses, Philos. T. R. Soc. B., 367, 3125-3134, 2012.

Lindsay, W. L. and Norvell, W. A.: Development of a DTPA soil test for zinc, iron, manganese, and copper, Soil Sci. Soc. Am. J., 42, 421-428, 1978.

Liu, X., Zhang, Y., Han, W., Tang, A., Shen, J., Cui, Z., Vitousek, P., Erisman, J. W., Goulding, K., Christire, P., Fangmeier, A., and Zhang, F.: Enhanced nitrogen deposition over China, Nature, 494, 459-462, 2013.

Marschner, H.: Mineral Nutrition of Higher Plants, Second Edn., Academic Press, London, 1995.

Maskell, L. C., Smart, S. M., Bullock, J. M., Thompson, K. E. N., and Stevens, C. J.: Nitrogen deposition causes widespread loss of species richness in British habitats, Glob. Change Biol., 16, 671-679, 2010.

Mulvaney, R. L.: Nitrogen:inorganic forms, in: Methods of Soil Analysis. Part 3, Chemical Methods, edited by: Sparks, D. L., Page, A. L., and Helmke, P. A., in: Soil Science Society of American and American Society of Agronomy, Madison, WI, USA, 1123-1184, 1996.

Olsen, S. R., Cole, C. V., Watanabe, F. S., and Dean, L. A.: Estimation of Available Phosphorus in Soils by Extraction with Sodium Bicarbonate, US Department of Agriculture, Washington, DC, 1-19, 1954.

Phoenix, G. K., Booth, R. E., Leake, J. R., Read, D. J., Grime, J. P., and Lee, J. A.: Effects of enhanced nitrogen deposition and phosphorus limitation on nitrogen budgets of semi-natural grasslands, Glob. Change Biol., 9, 1309-1321, 2003.
Smith, V. H., Tilman, G. D., and Nekola, J. C.: Eutrophication: impacts of excess nutrient inputs on freshwater, marine, and terrestrial ecosystems, Environ. Pollut., 100, 179-196, 1999.

Stevens, C. J., Dise, N. B., Mountford, J. O., and Gowing, D. J.: Impact of Nitrogen Deposition on the Species Richness of Grasslands, Science, 303, 1876-1879, 2004.

Stevens, C. J., Dise, N. B., Gowing, D. J. G., and Mountford, J. O.: Loss of forb diversity in relation to nitrogen deposition in the UK: regional trends and potential controls, Glob. Change Biol., 12, 1823-1833, 2006.

Stevens, C. J., Dise, N. B., and Gowing, D. J.: Regional trends in soil acidification and exchangeable metal concentrations in relation to acid deposition rates, Environ. Pollut., 157, 313-319, 2009.

Suding, K. N., Collins, S. L., Gough, L., Clark, C., Cleland, E. E., Gross, K. L., Milchunas, D. G., and Pennings, S.: Functionaland abundance-based mechanisms explain diversity loss due to N fertilization, P. Natl. Acad. Sci. USA, 102, 4387-4392, 2005.

Sutton, M. A. and Bleeker, A.: 2013 Environmental science: the shape of nitrogen to come, Nature, 494, 435-437, 2013.

Tian, Q., Chen, F., Zhang, F., and Mi, G.: Possible Involvement of cytokinin in nitrate-mediated root growth in maize, Plant Soil, 277, 185-196, 2005.

Tian, Q. Y., Sun, P., and Zhang, W. H.: Ethylene is involved in nitrate-dependent root growth and branching in Arabidopsis thaliana, New Phytol., 184, 918-931, 2009.

Tyler, G.: Soil chemistry and plant distributions in rock habitats of southern Sweden, Nord. J. Bot., 16, 609-635, 1996.

van den Berg, L. J. L., Dorland, E., Vergeer, P., Hart, M. A., Bobbink, R., and Roelofs, J. G.: Decline of acid-sensitive plant species in heathland can be attributed to ammonium toxicity in combination with low pH, New Phytol., 166, 551-564, 2005.

van Den Berg, L. J. L., Vergeer, P., Rich, T. C. G., Smart, S. M., Guest, D. A., and Ashmore, M. R.: Direct and indirect effects of nitrogen deposition on species composition change in calcareous grasslands, Glob. Change Biol., 17, 1871-1883, 2011.

van der Putten, W. H., Bardgett, R. D., Bever, J. D. Bezemer, T. M., Casper, B. B., Fukami, T., Kardol, P., Klironomos, J. N., Kulmatiski, A., Schweitzer, J. A., Suding, K. N., Van de Voorde, T. F. J., and Wardle, D. A.: Plant-soil feedbacks: the past, the present and future challenges, J. Ecol., 101, 265-276, 2013.

Wendt, K.: QuickChem method 10-107-04-1-A: Determination of nitrate/nitrite in surface and wastewaters by flow injection analysis. In Zellweger Analytics-Lachat Instruments methods manual, Zellweger Analytics, Milwaukee, WI, 1999.

Yang, H., Jiang, L., Li, L., Li, A., Wu, M., and Wan, S.: Diversitydependent stability under mowing and nutrient addition: evidence from a 7-year grassland experiment, Ecol. Lett., 15, 619626, 2012.

Yang, Y., Ji, C., Ma, W., Wang, S., Wang, S., Han, W., Mohammat, A., Robinson, D., and Smith, P.: Significant soil acidification across northern China's grasslands during 1980s-2000s, Glob. Change Biol., 18, 2292-2300, 2012.

Zhang, X., Wang, Q., Gilliam, F. S., Bai, W., Han, X., and Li, L.: Effect of nitrogen fertilization on net nitrogen mineralization in a grassland soil, northern China, Grass Forage Sci., 67, 219-230, 2012.

Zhang, Y., Lu, X., Isbell, F., Stevens, C. J., Han, X., He, N., Zhang, G., Yu, Q., Huang, J., and Han X.: Rapid plant species loss at 
high rates and at low frequency of $\mathrm{N}$ addition in temperate steppe, Glob. Change Biol., 20, 3520-3529., 2014.

Zhang, Y., Zheng, L., Liu, X., Jickells, T., Cape, J. N., Gouldng. K., Fangmeier, A., and Zhang, F.: Evidence for organic N deposition and its anthropogenic sources in China, Atmos. Environ., 42, 1035-1041, 2008.
Zhang, L. M., Hu, H. W., Shen, J. P., and He, J. Z.: Ammoniaoxidizing archaea have more important role than ammoniaoxidizing bacteria in ammonia oxidation of strongly acidic soils, ISME J., 6, 1032-1045, 2012.

Zhao, D. Y., Tian, Q. Y., Li, L. H., and Zhang, W. H.: Nitric oxide is involved in nitrate-induced inhibition of root elongation in Zea mays L., Ann. Bot., 100, 97-503, 2007. 